Abstracta Iranica Iranica

Revue bibliographique pour le domaine irano-aryen

Volume 31 | 2011

Comptes rendus des publications de 2008

\title{
Parthica - Incontri di culture nel mondo antico. Vol. 10, Pisa-Roma, 2008, 158 p.
}

\section{Carlo Lippolis}

\section{(2) OpenEdition \\ 1 Journals}

Édition électronique

URL : http://journals.openedition.org/abstractairanica/39538

DOI : 10.4000/abstractairanica.39538

ISSN : 1961-960X

\section{Éditeur :}

CNRS (UMR 7528 Mondes iraniens et indiens), Éditions de l'IFRI

\section{Édition imprimée}

Date de publication : 15 mai 2011

ISSN : 0240-8910

\section{Référence électronique}

Carlo Lippolis, « Parthica - Incontri di culture nel mondo antico. Vol. 10, Pisa-Roma, 2008, 158 p. », Abstracta Iranica [En ligne], Volume 31 | 2011, document 103, mis en ligne le 15 février 2012, consulté le 27 septembre 2020. URL : http://journals.openedition.org/abstractairanica/39538 ; DOI : https:// doi.org/10.4000/abstractairanica.39538

Ce document a été généré automatiquement le 27 septembre 2020.

Tous droits réservés 


\title{
Parthica - Incontri di culture nel mondo antico. Vol. 10, Pisa-Roma, 2008, $158 \mathrm{p}$.
}

\author{
Carlo Lippolis
}

1 The issue is published on the occasion of the $60^{\text {th }}$ anniversary of the discovery of the rhytons in Old Nisa.

2 The volume collects a useful set of studies and research carried out even recently, with particular reference for the Parthian period in Turkmenistan. The first paper, by A. Invernizzi, illustrates the activities of Jutake as an important institution for Central Asian archaeology, while the discovery of the Nisa ivory rhytons on 25th September 1948 is narrated by V. M. Masson and some aspects of the political propaganda of the first Arsacids are discussed by E. DĄbrowa. V. N. Pilipko provides an overview of old Nisa's monumental complex (layout, interpretation and chronology), while a preliminary report of new italo-turkmen works (2007) in the southern part of Mitrhadatkert is presented by C. Lippolis and V. Messina. E. Pappalardo and $\mathrm{N}$. Manassero compiled two iconographic studies about the friezes and the cornices of the Nisa rhytons. Further on, the contribution of V. A. Gaibov and G. A. Košelenko analyzed the scene "horseman vs. foot-soldier", a rather new iconography for Parthian glyptic art. For the site of Merv, G. Puschnigg introduces some Hellenistic features in the local pottery repertoire. Preliminary remarks on the recent Polish-Turkmen survey of the Serakhs Oasis, with reference to the Parthian period, is then provided by B. Kaim. In the end, the iconographic study of K. A. Abdullaev on a Bactrian gold buckle with a contest scene between a hero and a centaur. 
INDEX

Thèmes : 3.2.3. Séleucides, Parthes et Sassanides

\section{AUTEURS}

CARLO LIPPOLIS

Università di Torino 